\title{
The Phenomenon of (Sustainable) Tourism Activities on Farms in Slovenia During the COVID-19 Pandemic
}

\author{
Zjawisko (zrównoważonej) turystyki w działalności gospodarstw rolnych w Słowenii podczas \\ pandemii COVID-19
}

\author{
Maja Žibert ${ }^{1}$, Boris Prevolšek ${ }^{2}$ \\ ${ }^{1}$ Faculty of Agriculture and Life Sciences, University of Maribor, Slovenia \\ ${ }^{2}$ Faculty of Tourism, University of Maribor, Slovenia \\ ORCID MŽ https://orcid.org/0000-0003-3804-4749; BP https://orcid.org/0000-0002-4700-3589 • maja.zibert@student.um.si \\ Received: 14 Oct, 2021; Revised: 23 Nov, 2021; Accepted: 6 Dec, 2021
}

\begin{abstract}
The outbreak of the COVID-19 pandemic is the reason why the development trends of the tourism industry are changing today. The purpose of this article is to address issues of future tourism industry development, linking it to elements of sustainable development trends. The article presents the main elements of the sustainable concept of rural and farm tourism. Using the method of compilation and description, we want to check, based on statistical data related to farm tourism activities in Slovenia (before and during the COVID-19 pandemic), whether it is possible to detect development trends in Slovenia, in the direction of sustainability that are linked to the concept of farm tourism. This study also aims to identify a number of measures that can improve sustainability at the farming tourism level in Slovenia, in a post-COVID phase. According to the findings of numerous comparisons and statistical analysis, it can be stated that the future development trends show a great need to develop the decarbonisation of the industry, digitalisation of industry, and the involvement of the local population in the provision of services. In the present global situation, we have reached a point where it will be necessary to focus on sustainable and digital forms of the industry, in order to further post-COVID development of the tourism industry.
\end{abstract}

Keywords: COVID-19, post-COVID world, sustainable tourism, farm tourism, Slovenia, future development

Streszczenie: Wybuch pandemii COVID-19 spowodował, że zmieniają się trendy rozwojowe branży turystycznej. Celem tego artykułu jest zbadanie aktualnego rozwoju branży turystycznej i powiązanie go z elementami trendów zrównoważonego rozwoju. W artykule przedstawiono główne elementy koncepcji zrównoważonej turystyki wiejskiej i agroturystyki. Za pomocą metody zestawienia i opisu autorzy badają, na podstawie danych statystycznych dotyczących działalności agroturystycznej w Słowenii (przed i w trakcie pandemii COVID-19), czy możliwe jest stwierdzenie tendencji rozwojowych w zakresie zrównoważonego rozwoju w kontekście agroturystyki. Niniejsze badanie ma również na celu zidentyfikowanie szeregu czynników, które mogą poprawić zrównoważony rozwój turystyki rolniczej w Słowenii w okresie po COVID-19. Wyniki przytoczonych badań i ich analiza wskazują, że przyszłe trendy rozwojowe domagają się dekarbonizacji i cyfryzacji przemysłu oraz zaangażowania społeczności lokalnej w świadczenie usług. Aktualna globalna sytuacja gospodarcza wskazuje, że dotarliśmy do punktu, w którym dla rozwoju branży turystycznej konieczne jest wdrażanie zrównoważonych i cyfrowych modeli przemysłu.

Słowa kluczowe: COVID-19, świat po COVID, świat po COVID, zrównoważona turystyka, turystyka wiejska, Słowenia, przyszły rozwój 


\section{Introduction}

There is no doubt today, that the pandemic of COVID-19 has cut into every pore of our lives. Many scientists and researchers have recently analysed the effects of COVID-19, on the course and development of tourism, at any given time. At one time, discussions often focused on questions about how tourism development would be reflected in the future when the pandemic is finally defeated (Chin et al., 2021). This is mainly because we cannot deny the fact that tourism, especially in the last period, when it reached such high levels of growth and scale, was (co)responsible for planetary pollution, climate change, congestion, dissatisfaction of the local population, and huge social inequalities. Tourism, naturally, also presents a number of advantages (DeRosa et al. 2019; Huang et al. 2016; Cassel and Pettersson 2015; Crumley 2010; Barbieri et al. 2008; Barbieri and Mshenga 2008; Ilbery et al. 1998; Williams and Shaw 1998; Oppermann 1996). Cavaco (1995) addresses the question of tourism in the context of the economic challenges of rural areas.

With the emergence of the COVID-19 pandemic, we seem to have reached a point where we need to ask ourselves: what kind of tourism do we want in the future? The purpose of this paper is to analyse the trends of tourism development, during and after the period of the COVID-19 pandemic. Trends in the development of activities, place great emphasis on the concepts of sustainable development. Using the method of compilation and description, we want to check, based on statistical data related to farm tourism activities in Slovenia, whether it is possible to detect development trends in Slovenia, in the direction of sustainability that are linked to the concept of farm tourism.

\section{Tourism development trends after the end of the COVID-19}

The pandemic of COVID-19, which spread all over the world in March, 2020, also left a very big and important mark in the field of management and organisation of tourism activities. According to UNWTO (2020), Sigala (2020), Gretzela et al. (2020), the number of international tourists in the world decreased by $74 \%$, due to the consequences of the pandemic in 2020. Simultaneously, about one trillion US dollars of revenue from activities was lost. UNWTO (2020) also reports that in April, 2020, travel restrictions were introduced in 217 countries - related to the COVID-19 pandemic. In as many as 107 countries, the borders were closed, or they disconnected air connections for more than 4 weeks. According to Lenzen et al. (2018), between 2009 and 2013, the global carbon footprint of tourism increased from 3.9 to $4.5 \mathrm{GtCO}_{2} \mathrm{e}$, which is four times more than in the previous period. At the same time, this figure represents about $8 \%$ of global greenhouse gas emissions. Numerous studies report the (negative) impacts of airlines, (also for tourism purposes), on environmental pollution (May, 2016; Deng et al. 2019), high energy use, high water consumption, and habitat destruction during tourism activity (Pan et al. 2018). In her research, McCabe (2019) also discusses social inequalities that occur in different contexts of tourism development.

It is true, that already in the 1990 s, the tourism profession and science offered a framework for tourism policy planning, which must set sustainability as a key challenge, in addition to competitiveness (Goeldner and Ritchie 2012). However, we still think we have arrived at a turning point with the onset of the COVID-19 pandemic, when all of a sudden, we all wonder again how to proceed, how to get back to the numbers in the development we achieved in 2019, whilst changing and correcting the mistakes we made - especially in terms of (un)sustainable development in the field of environment, economy, society, and the countryside.

In his research, Higgins-Desbiolles (2019) identifies the emergence of the COVID-19 pandemic as a rare and invaluable opportunity to rethink the shift of tourism to a better future. He emphasises that the very concept 
of "responsible" tourism will not yet address all the pressing issues. In the research, he takes his position with regard to the socially-oriented tourism frameworks that destinations must achieve in order to redirect tourism based on the rights and interests of individual local communities and nations. Theoretically, such an approach would encompass the method by which tourism could become "public property" through its focus on the public good. Simultaneously, tourism must also be responsible for social and ecological constraints around the world. Furthermore, Brouder (2020) discusses in his paper possible evolutionary pathways to the transformation of tourism after COVID-19. In his research, he explains that COVID-19 will leave traces on the demand and supply of tourism. Also, it will have long-term growing effects in the coming years. He adds that we will eventually witness a transformation in tourism.

According to Niewiadomski (2020), one consequence of the outbreak of COVID-19 was the fact that the entire travel and tourism sector stopped in a certain period. He adds that the price paid by the world because of it, is enormous. The time processes of globalisation offer the tourism industry an opportunity to relaunch without precedent, an opportunity to redevelop following the principles of sustainable development, and to eliminate various "dark sides" of tourism development, such as environmental destruction, economic exploitation, or overpopulation. At the same time, he emphasises that the path of renewal and transformation, which the global tourism industry system will follow, after the COVID-19 crisis, has not yet been determined. Meanwhile, Gössling, Scott, and Hall (2021) are already more grounded in their study. Namely, they advise that to achieve sustainable tourism, a long-term transformation into more resilient destinations would be necessary. In particular, they suggest finding solutions within domestic forms of tourism. As an example, they suggest agrotourism, or sustainable activities related to rural tourism development.

\section{Sustainable tourism planning}

In the early 1990s, two of the key documents in the field of sustainable development emerged - the Brundtland report titled: "Our Common Future" (WCED 1987), prepared by the World Commission on Environmental Development. It explains sustainable development as "a process of change, where the exploitation of natural resources, the direction of investment, technological progress, and institutional change, are in line with both current and future needs" or, more simply, this is the "development that meets today's needs, without jeopardizing the ability of future generations to meet their own needs". A similar weight was borne by Agenda 21 (UNEP 2003), drafted at the United Nations conference in Rio de Janeiro. These two events established the use of the term "sustainable development" and introduced the concept into various spheres of life (referring mainly to the context of society, the environment, and the climate). Thus, sustainable development planning of various economies and societies has become a basic concept and challenge for many national and international strategies.

Today's efforts to support sustainable development are tied to a 2015 event, where world leaders pledged to eradicate poverty and prevent climate change and injustice at the historic United Nations Summit in New York. The 2030 Agenda, created as part of the sustainable development session, offers a better future for billions of people around the world, and our planet as a whole. At the same time, 193 countries unanimously adopted 17 sustainable development goals, which became the new universal standard for sustainable development. In the implementation of these goals, it is crucial to ensure that we do not forget anyone. The indicators behind the objectives, provide clear benchmarks for measuring performance. The 2030 Agenda for Sustainable Development is universal and indivisible. It calls on all countries, both developed and developing, and the people to act 
to eradicate poverty, and prevent climate change and injustice.

Due to the impact of the COVID-19 pandemic, many of the objectives set out in the document presenting these 17 sustainable development indicators in 2020, have not been achieved (UNIS 2021). Among other things, the world did not meet the 2020 targets, to halt the loss of biodiversity and the loss of 10 million hectares of forest, each year, between 2015 and 2020 , which will certainly be felt in the long-term in the field of sustainable tourism management.

Sustainable principles of tourism refer to the ecological, economic, and socio-cultural aspects of development. In the process, it is necessary to establish an appropriate balance, and to ensure long-term sustainability between these three aspects (UNWTO 2004).

The eighth and the twelfth Sustainable Development Goals, which address decent work and economic growth as well as responsible consumption and production, specifically address the need to formulate and implement policies for the development of sustainable tourism, to create jobs and promote local culture and products by 2030 . Thus, tourism, as one of the world's largest industries, is an important building block in the implementation of sustainable goals.

Sustainability is an integral part of tourism policy and tourism development planning (Wall and Mathieson 2006; Goeldner and Ritchie 2012; Hall 2008; Edgell and Swanson 2019). This mindset has been endorsed by all UNWTO members, because they pointed out sustainability as a goal for the development of the industry, connecting it to either efficiency or competitiveness. (UNWTO 2019).

One of the successful ways to help destinations develop and manage, and reward sustainable destination management, is via the implementation of a system of (green) certification of destinations and providers. It is a way to help operators measure levels of sustainability, and communicate with consumers, indirectly through certificates.
The first better-known certification appeared in 1985 in France - the Blue flag sign evaluated natural baths. The Silberdistel logo was used to mark accommodation and restaurants in Austria. By 2002, more than 60 tourism environmental certification programmes were developed worldwide. Through them, the socio-cultural aspect of destination management and the experience, was also evaluated (Bien 2011).

Scientific studies report several positive effects of certification schemes on the sustainable development of tourism (Jarvis et al. 2010; Haaland and Aas 2010; Mzembe et al. 2020).

The farm tourism sector is an ideal environment for the development of sustainable tourism, also in Slovenia. Farms that offer tourism as a complementary activity, are often located close to nature, with tourists having the opportunity to experience nature (hiking, biking, etc.), the environment is often clean, unpolluted. The farms offer home-grown produce, and visitors often have the opportunity to observe the fauna and flora in their home environment. It also proved to be an ideal environment for tourism during the Covid-19 pandemic, as farm accommodation providers are often more isolated (which poses less health risk) than, for example, larger hotels.

\section{Farm tourism - sustainable tourism?}

In scientific literature, rural tourism is equated with the term "tourism" on farms, or it is presented as a secondary branch (Sharpley and Vass 2006). We also talk about activities that were long considered effective promoters of rural development. It is an important element in the field of farm diversification (Evans and Ilbery 1989; Hjalager 1996). The development of rural tourism as a form of entrepreneurial activity in rural areas, requires justification of many aspects that must encourage the further development of activities, and also ensure an appropriate level of competition, because this has a significant impact on market conditions (Boiko 2020). 
Therefore, the question arises whether activities related to the development and management of tourism on farms and in the countryside directly address the elements of sustainable development and destination management. In the following, based on a review of scientific literature and world practices, we formulated the main advantages and factors of rural tourism that contribute to sustain rural development, whilst also representing the synergistic effects of tourism on rural areas. We combined them into 5 areas:

\section{Farm tourism as a nature-friendly activity}

The activities of tourism on farms are already sustainable in their essence, because activities that promote a responsible and respectful way of working towards the natural, cultural, and social environment, are encouraged and implemented on farms. Primary agricultural activities, such as food production, are important in terms of supplying the global population, as well as in terms of many national cultural identities, natural resource management, and spatial development (Mariya Peneva and Kazakova-Mateva 2015). Farms have been striving for sustainable forest management for centuries (Sargent and Bass 2019). Nowadays, many farms strive for an innovative approach to managing activities, the so-called "green supply", which combines care for people and land on farms, with elements that once were not related: (1) multi-functional agriculture and recognition of the plurality of values of the agricultural system, (2) social services and healthcare, and (3) the possibility of strengthening the agricultural sector and local communities (Garcia-Llorente et. al 2018).

In Slovenia, more than 200 tourist farms focus on organic farming. At the same time, we can sense that a larger share of farms, engaged in tourism as a complementary activity, is included in agri-environmental climate measures (AFIC 2020).

\section{Promoting sustainable infrastructure}

Numerous researchers have been writing about the positive effects and possibilities of carrying out many activities in nature, as part of tourism on farms (Petrović et al. 2017; Thilmany et al. 2019; Satumane and Doganer 2018; Senturan and Kokturk 2017). In Slovenia, hiking in nature, various mountain hikes, cycling, horseback riding, water sports on rivers, and winter sports, such as cross-country skiing, skating, and sledding, are especially popular as part of holidays on tourist farms. Nowadays, many farms also offer their customers the possibility of observing and photographing animals, plants, and landscapes.

The Chamber of Agriculture and Forestry (2018) reports about the statistics of activities in the field of supplementary activities on agricultural holdings, in a document titled: "Analysis of the state of supplementary activities". The spread of the offer is reported by many tourist farms, including Eko kmetija Mikl (2021), Turistična kmetija pri Martinovih (2021), Alpine homestead (2021).

The fact is that farms use their activities to promote sustainable practices, and the use of transport infrastructure, especially cycling, which is flourishing today (many farms offer their guests the possibility of renting bicycles or e-bikes).

\section{Authenticity as a competitive advantage}

The concept of authenticity plays an important role in experiencing a tourist experience (Pearce and Moscardo 1986). When we talk about the authenticity of the offer on tourist farms, the scientific literature mainly mentions storytelling (Mei et al. 2020), as a way, based on the experience of transferring the knowledge and skills of farming activities of the farming family (hosts) onto tourists. We are talking about knowledge and skills, such as getting to know the typical cuisine of the area, products of home arts and crafts of the area, and cultural heritage (customs and habits) of the area.

As the market is increasingly saturated and competitive, while modern consumers are 
increasingly ecologically aware, many destinations strive to create and offer the most acceptable tourism products that are both sustainable and unique, to attract as many modern tourists, i.e. consumers, as possible (Jakovič et al. 2015). One example here are certainly tourist farms, which can offer the modern sustainably aware consumer an authentic experience of living on a tourist farm.

\section{Saving water and energy}

A review of the literature shows that there are not many researchers who would deal with the analysis of environmental protection, especially with the saving of water and energy in the context of tourism on farms. To a lesser extent, environmental protection has been analysed. In many cases, it is based only on compliance with environmental legislation, at a given time (Villanueva-Álvaro et al. 2017). Ge and contemporaries (2017) find in their study, that diversified farms are more likely to use renewable energy sources, especially solar energy and energy from biomass. In their research, they identified essential factors on farms in Scotland influencing the decision to adopt renewable energy production (wind, solar energy, and biomass). They ascertained that, in addition to the demographics of farm owners and farm business structures, the decision to use renewable energy sources is most often influenced by diversification activities, such as tourism and forestry, as well as the spatial, biophysical, and geophysical characteristics of farms (Ge et al. 2017).

The Agricultural and Forestry Institute Celje (2020) from Slovenia, reports similarly. On their websites, they report that most tourist farms in Slovenia use renewable energy sources for heating and water heating, especially firewood or wood chips. The following fact is significant: the food served on tourist farms is produced on-site, therefore, services, such as food delivery, do not pile up redundant packaging, as would be the case, if the food had to be brought from shopping centres or elsewhere.

\section{Kindness and hospitality of families}

Numerous studies explore the involvement of kindness and hospitality of farm families as one of the important virtues in running a tourist economic activity on an agricultural holding (Roman 2015; Cornelia et al. 2017). Tomas (2012) also points to hospitality as an important element of a tourist product from a business point of view. The fact is that kindness and hospitality cannot be reduced and generalised as a traditional feature of regional identity. Namely, it is largely a learned and professional virtue, that shows the character traits of the individual (Orlic and Brscic 2012). Nevertheless, the family atmosphere (kindness of the hosts and hospitality) represents the basic, and yet, one of the biggest advantages of the countryside, as part of the provision of tourism on farms (Radnič et al. 2012).

Based on a review of the literature and many related practices, therefore, we can confirm the fact that farm tourism, as one of the manifestations of tourism, has a significant impact on rural development, and also, with appropriate management, may provide bases for the development of green and sustainable activities.

In the conducted study, the Celje Agricultural and Forestry Institute (2020) identifies as an example of good practice, the factors of rural tourism that contribute to sustainable rural development, and at the same time, represents the synergistic effects of rural tourism in Slovenia. The study touches on all 5 identified areas.

\section{Farm tourism in Slovenia}

In Slovenia, farm tourism is one of the important supplementary activities that can be registered by individual agricultural holdings. Based on activities and legal regulations, we divide it into catering and non-catering. In Slovenia, tourism on farms with catering activity is represented by wine shops, "osmica", excursion farms, and tourist farms with accommodation. Table 1 below presents statistical data on the latter in Slovenia in 2018 and 2019 (MKGP 2020). 
Due to the increased number of visits by mainly foreign tourists, the number of tourists on tourist farms has increased in the last four years by $15 \%$ per year on the average, reaching in some cases even a $50 \%$ growth or more (SORS 2020). In Slovenia, the supplementary activity of farm tourism has a long tradition. At the same time, it is considered one of the most demanding supplementary activities on farms. Due to the high demand of both domestic and foreign tourists for this type of offer, the number of these farms has more than doubled in the past twenty years. Given the current trends in tourism, tourist farms in the Slovenian tourist offer represent an exceptional diversification, because the current trend in tourism means a return to nature and authenticity.

In Table 1, we can see the data that the biggest jump in the increase in the number of tourist farms in Slovenia from 2018 to 2019 , was made exactly by the form of tourist farms with accommodation. In total, the number of registered tourist farms with accommodation, increased from 2018 to 2019 by 35 .

Figures 1 and 2 show data on the number of tourist farms with accommodation by individual statistical regions of Slovenia in 2018 and 2019.

The data further confirms that tourist farms (including those with accommodation) develop mainly in wine-growing, bathing, and spa areas, as well as in the Alpine or pre-Alpine world. However, there are also some that are tied to the hinterlands of regional centres - the city of Ljubljana, plus Maribor, Celje, and Novo mesto.

\section{The phenomenon of Slovenian tourist farms during the COVID-19 pandemic}

The year 2019 was a record year for Slovenian tourism, because the highest number of tourist arrivals and overnight stays was recorded in tourist accommodation establishments so far: more than 6.2 million tourist arrivals, which was $5.0 \%$ more than in 2018, and almost 15,8 million overnight stays of tourists or $0.5 \%$ more than in 2018 . Domestic tourists accounted for $24.5 \%$ of the number of tourist arrivals in 2019, and $27.9 \%$ of the number of overnight stays. The majority of overnight stays of the foreign tourists who visited Slovenia in 2019, were made by Germans - 9.7\% of all overnight stays by foreign tourists. They were followed by Italians $-8.1 \%$ and Austrians - 6.4\%. In Slovenia, too, tourism represents an extremely important industry, employing $6.5 \%$ of all employees in 2019 , and contributing $5.3 \%$ to GDP (SORS 2020).

However, in Slovenia, too, tourism activity in 2020 was severely curtailed due to the COVID-19 pandemic. The number of tourist overnight stays reached only $58 \%$ of the value reached in 2019. Half of them were generated in just two months, in July and August (SORS, 2021). In Figure 3, we can see the trends in the annual growth rate of tourist overnight stays in Slovenia.

In terms of types of accommodation establishments, tourists in Slovenia in 2020, generated the most overnight stays in hotels, slightly less than 3.6 million (or $39 \%$ of all tourist overnight stays in 2020). More than a million tourist overnight stays were generated only in private rooms, apartments, and houses (2.2 million or $24 \%$ of all) and in

Table 1. Number of tourist farms with catering activity in Slovenia in 2018 and 2019

\begin{tabular}{|c|c|c|}
\hline Types & 2018 & 2019 \\
\hline Excursion farms & 476 & 480 \\
\hline Wine shops & 95 & 102 \\
\hline Osmica & 32 & 37 \\
\hline Tourist farms with accommodation & 472 & 507 \\
\hline TOTAL & 1.075 & 1.126 \\
\hline
\end{tabular}




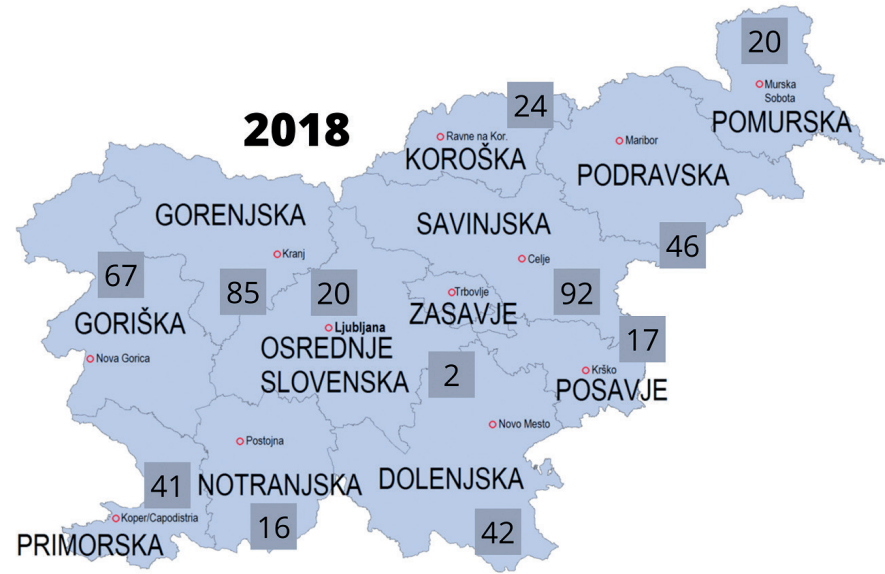

Figure 1. The number of tourist farms with accommodation by statistical regions in Slovenia in 2018. Source: Prepared according to MKGP 2020 data

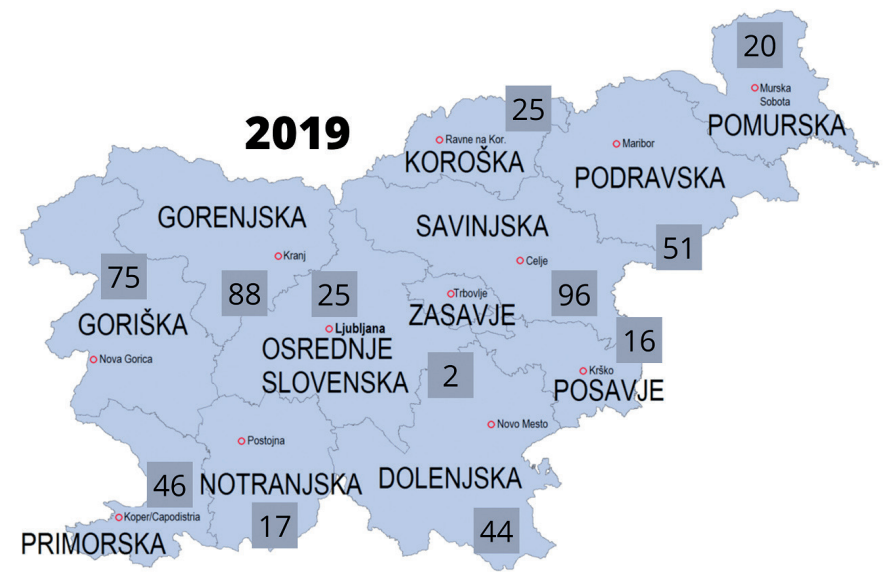

Figure 2. The number of tourist farms with accommodation by statistical regions in Slovenia in 2019. Source: Prepared according to MKGP 2020 data

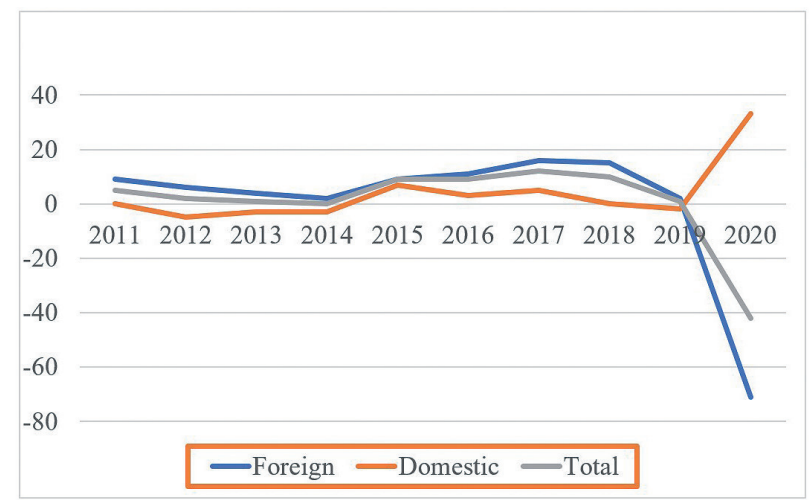

Figure 3. Annual growth rates of tourist overnight stays, Slovenia. Source: SORS 2021 
campsites (1.4 million or $15 \%$ of all). In 2020 , about 250,00o tourist overnight stays were created in tourist farms with accommodation, which was about as many as in 2019, except that the numerical ratio between overnight stays of domestic and foreign tourists was reversed. In 2019, foreign tourists generated $79 \%$ of all overnight stays on tourist farms, but only $25 \%$ in 2020 (SORS 2021). We show the data in Table 2 below.

To date, the Ministry of Agriculture, Forestry and Food, AJPES (Agency of the Republic of Slovenia for Public Legal Records and Related Services), and the Statistical Office of the Republic of Slovenia, have not been able to obtain precise data on the number of individual establishments of tourist farms that have engaged in catering activities.

However, since the Government of the Republic of Slovenia introduced special vouchers in June 2020, the so-called tourist stamps, with the purpose of eliminating the consequences of the COVID-19 pandemic in tourism, i.e., to improve the economic situation in the field of tourism, we obtained data on the cashing of tourist vouchers on tourist farms in Slovenia, at the Financial Administration of the Republic of Slovenia (FURS 2021).

Initially, vouchers could be cashed from June 19 to December 31, 2020. In December 2020, however, the Government of the Republic of Slovenia adopted an extension of vouchers until December 2021. Vouchers can be used in Slovenia to pay for accommodation or bed and breakfast with tourist service providers. The decree stipulated that tourist vouchers were received by all residents of Slovenia with permanent residence in the country, on March 13, 2020. All adults or persons who reached the age of 18 in 2020 , received a voucher of 200 EUR. Minor beneficiaries received a voucher of 50 EUR. Vouchers are not taxed. Their partial transferability is possible.

Based on the obtained data, we ascertained that from the beginning of the cashing of tourist vouchers (from June 19, 2020, to August 30, 2021), Slovenians cashed $1,351,682(66 \%)$ tourist vouchers to the total value of 190,522,062.07 EUR. Of this, a total of 6,959,571.90 EUR was spent on a total of 388 tourist farms. According to the obtained statistical data, we analysed the number of cashed tourist vouchers on tourist farms by region, and ascertained that compared to 2019, there were fewer tourist farms, or the tourists cashed vouchers on fewer tourist farms. The number of farms on which domestic tourists used tourist vouchers is shown in Figure 4 below. At this time, two explanations are possible. Either certain farmers closed their tourist establishments, due to the pandemic in the regions, or tourist vouchers were not cashed in some of them, because of "promotional inactivity".

Table 2. Tourist arrivals and overnight stays by types of accommodation establishments in Slovenia in 2020

\begin{tabular}{lcccc}
\hline \multirow{2}{*}{\begin{tabular}{l} 
Types of accommodation \\
\cline { 2 - 5 }
\end{tabular}} & \multicolumn{2}{c}{ Tourist arrivals } & \multicolumn{2}{c}{ Overnight stays } \\
\cline { 2 - 5 } & 2020 & 2020 & 2020 & 2020 \\
2019 \\
\cline { 2 - 5 } Total & Number & Index & Number & Index \\
\hline Hotels & $3,065,085$ & 49.2 & $9,204,374$ & 58.3 \\
\hline Private accommodations - rented rooms, dwellings & $1,252,802$ & 41.0 & $3,596,306$ & 49.1 \\
\hline Camping sites & 674,617 & 57.4 & $2,242,571$ & 68.5 \\
\hline Apartment settlements & 450,474 & 63.1 & $1,419,250$ & 69.7 \\
\hline Tourist farms with accommodation & 95,938 & 69.9 & 385,812 & 74.3 \\
\hline
\end{tabular}

Source: SORS 2021 
Although our data, through which we compare the statistics of tourist farms with accommodation in Slovenia in 2019 and 2020 , show a sharp decrease in the number of individual establishments (507 tourist farms in 2019, and only 388 in 2020), as we ascertained earlier, farms are the only type of accommodation establishments that maintained the number of overnight stays compared to the previous year. Upon careful review of the data obtained by the Financial Administration of the Republic of Slovenia, it was also ascertained that, on farms where individuals cashed a tourist voucher, the average income between June 19, 2020, to August 30, 2021, was a little less than 18 , 000 EUR (only from tourist vouchers), while in 2019, the average income from tourism on an individual farm, was just a bit more than 6,500 EUR (Žibert et al. 2021).

According to obtained data and the performed analysis, which we have highlighted in this research, we can agree that tourism on farms will be a further trend in the development of the tourism industry, even after the end of the COVID-19 pandemic. It has firmly proven to be a popular activity, supported by sustainable principles, during the pandemic, itself.

For further investigation and verification of the facts related to tourism trends during the COVID-19 pandemic, it is necessary to check thoroughly with complementary providers what measures they have taken to curb the spread of the SARS-CoV-2, what they consider to be the advantages over other types of tourist accommodation, and where there are more opportunities to reach the level (according to the number of providers), which the activity reached before the outbreak of the pandemic, as quickly as possible, as a type of tourism activity. It would also be interesting to check why certain holdings have closed their activities, and to compare statistical and qualitative data, also with other neighbouring or other European countries.

However, both Slovenia and, consequently, tourist farms also face many challenges in terms of the development of sustainability concepts. It refers to several areas: sustainable management of offers and destinations, socio-economic sustainability, sustainability in the field of cultural heritage and environmental sustainability (Greenglobe 2021).

Today, many providers of accommodation and other forms tourism, such as tourist farms, are not yet included in the so called "Green Scheme of Slovenian Tourism", which in Slovenia, provides the foundation of a sustainable structure. This national programme is a certification scheme and communication tool, which is intended for accommodation providers, as well as destinations, nature

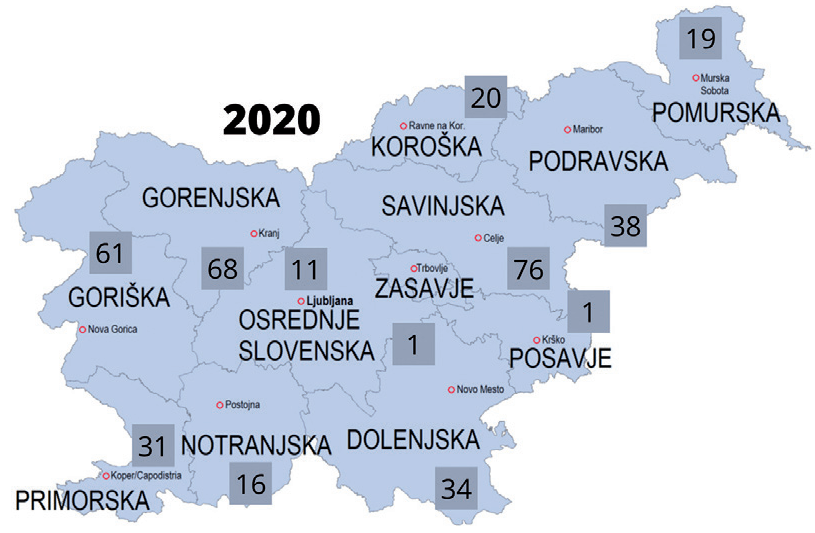

Figure 4. The number of tourist farms with accommodation by statistical regions in Slovenia in 2020. Source: Prepared according to MKGP 2020 data 
parks, tourist attractions, restaurants and beaches. By joining the Green Scheme, providers receive a certificate of sustainable management of service activities, which include many areas, for example:

- providers have a long-term sustainability management system in place;

- the operations of tourism service providers comply with all relevant international and / or local laws and regulations;

- all staff are regularly educated on their role in managing environmental, socio-cultural, health and safety practices;

- customer satisfaction is measured and corrective action is taken if necessary;

- promotional materials are accurate and complete and do not promise more than the provider can deliver;

- clients are provided with information and interpretation of the natural environment, local culture, and cultural heritage, as well as an explanation of appropriate behaviour when visiting natural areas, residential cultures, and cultural heritage sites;

- the local population is employed;

- local crafts are supported;

- the tourist, and other offers include elements of local art, architecture... while respecting the intellectual property rights of local communities;

- the purchase of disposable goods is measured, and ways to reduce their use are sought;

- energy consumption is measured, and steps are taken to reduce total energy consumption, while promoting the use of renewable energy sources;

- water consumption is measured, and steps are taken to reduce overall consumption;

- waste is treated systematically;

- biodiversity of ecosystems and landscapes is preserved.

The strategies described above, are just one of the examples of achieving the measures of one of the internationally accredited certification schemes (Green Globe), according to which, standards are set in the Slovenian Green Scheme, which represent the standard and strategies for the management of sustainable tourist accommodation. At the same time, we understand the phase of recovery (mentioned by many authors in the international arena) after the end of the Covid-19 epidemic, to be a standard for achieving the mentioned criteria for the revival of tourism, including farm tourism.

\section{Conclusion}

The tourism industry in Slovenia is in a difficult position during the COVID-19 pandemic. To help its recovery, the state of the Republic of Slovenia helped with numerous forms of assistance, including the intervention law on tourism, compensation for waiting for work for tourist workers, and special vouchers, which were intended for all citizens of the Republic of Slovenia, for overnight stays or bed and breakfast at any tourist service provider in Slovenia. In the present global situation, we have reached a point where it will be necessary to focus on sustainable and digital forms of industry in order to further post-covid development of the tourism industry. It seems that such a value as a destination's safety (understood as health safety) has never been as important as it is today. Development trends show a great need to develop the decarbonisation of the industry, the involvement of the local population in the provision of services, and at the same time, the satisfaction of the local population as well as tourists.

Rural tourism, as well as farm tourism, already covers most of the above-mentioned practices, which are becoming trends for future post-covid development. In 2020 , when the COVID-19 pandemic broke out, rural tourism (farm tourism) in Slovenia was the only form of tourism that did not suffer a significant drop in the number of overnight stays compared to the previous year, despite the fact the analysis of statistical data showed the number of accommodation establishments decreased. 
However, the decarbonisation and digitalisation of the industry are not the only indicators of the future sustainable development of the industry. The concept of sustainability on Slovenian tourist farms is already defined by activities related to spending free time in nature (offering many activities - hiking, biking, horseback riding, fishing, etc.) in a clean environment, where visitors have the opportunity to learn about local vegetation and animals. In contrast to the practices of mass tourism, also in Slovenia, tourism on farms is characterised by authenticity in terms of individual person focused offers, which can be adapted, for example, by offering eco-organically produced goods and by raising sustainable awareness of the industry, among others, by using renewable energy sources. However, Slovenia, along with accommodation providers on tourist farms, as we found out (Green Glob, 2021; Green Key 2021), still have many opportunities to upgrade the concepts of sustainability.

Author Contributions: Conceptualisation, M.Ľ. and B.P.; Methodology, M.Ž.; Validation, M.Ž. and B.P.; Formal Analysis, M.Ž.; Investigation, M.Ž.; Writing - Original Draft Preparation, M.Ž. and B.P.; Writing - Review \& Editing, M.Ž. and B.P.; Visualisation, M.Ž.; Supervision, B.P. Both authors have read and agreed to the published version of the manuscript.

Funding: This research received no external funding. Institutional Review Board Statement: Not applicable.

Conflicts of Interest: The authors declare no conflict of interest.

Acknowledgments: Special thanks to Mr. Stojan from FURS, who invested his time in collecting and providing statistical data regarding the use of tourist vouchers in the Republic of Slovenia.

\section{References}

AFIC (The Agricultural and Forestry Institute Celje). 2020. Dopolnilne dejavnosti. Accessed September 15, 2021. https://www.kmetijskizavodcelje.si/aktualno/trendi-v-turizmu-ki-so-v-pridturisticnim-kmetijam-2020-11-17.

Alpine homestead. 2021. Domačija na robu gozda. Accessed November 20, 2021. https://www.alpinehomesteadbled.com/sl/ alpine-homestead-bled/.

Barbieri, Carla and Patience M. Mshenga. 2008. "The role of the firm and owner characteristics on the performance of agritourism farms." Sociologia Ruralis 48(2): 166-183.

Barbieri, Carla, Edward Mahoney, and Larry Butler. 2008. "Understanding the nature and extent of farm and ranch diversification in North America." Rural Sociology 73(2): 205-229.

Bien, Amos. 2011. A simple user's guide to certification for sustainable tourism and eco-tourism. Washington, D.C.: Center for Ecotourism and Sustainable Development.

Boiko, Viktoriia. 2020. Green tourism as a perspective direction for rural entrepreneurship development. Lviv-Toruń: Liha-Pres.

Brouder, Patrick. 2020. "Reset redux: Possible evolutionary pathways towards the transformation of tourism in a COVID-19 world." Tourism Geographies 22(3): 484-490.

Cassel, Susanna Heldt, and Katarina Pettersson. 2015. "Performing gender and rurality in Swedish farm tourism." Scandinavian Journal of Hospitality and Tourism 15(1-2): 138-151.

Cavaco, Carminda. "Rural tourism: The creation of new tourist spaces." In European tourism: region, spaces and restructuring edited by Armando Montanari, Allan M. Williams, 127-149. New York, N.Y.: Wiley.

Chin, Wei Lee, and Siti Fatimahwati Pehin Dato Musa. 2021. "Agritourism resilience against Covid-19: Impacts and management strategies." Cogent Social Sciences 7(1): 1950290. https://doi. org/10.1080/23311886.2021.1950290.

Crumley, Bruce. 2010. "How to save rural France." Time Magazine, August 02, 2010.

De Rosa, Marcello, Gerard McElwee, and Robert Smith. 2019. "Farm diversification strategies in response to rural policy: A case from rural Italy." Land use policy 81: 291-301.

Deng, Taotao, Xin Li, and Mulan Ma. 2017. "Evaluating impact of air pollution on China's inbound tourism industry: A spatial econometric approach." Asia Pacific Journal of Tourism Research 22(7): 771-780.

Edgell Sr, David L., and Jason R. Swanson. 2013. Tourism policy and planning: Yesterday, today, and tomorrow. London: Routledge. 
Eko kmetija Mikl. 2021. Dejavnosti. Accessed November 20, 2021. https://www.eko-kmetija. si/dejavnosti.

Evans, Nicholas J., and Brian W. Ilbery. 1989. "A conceptual framework for investigating farmbased accommodation and tourism in Britain." Journal of Rural Studies 5(3): 257-266.

FURS - Finančna uprava Republike Slovenije. 2021. Statistika o turističnih bonih na dan 30.8.2021. (Internal material, Ljubljana: FURS - Finančna uprava Republike Slovenije).

Garcia-Llorente, Marina, Radha Rubio-Olivar, and Ines Gutierrez-Briceno. 2018. "Farming for life quality and sustainability: A literature review of green care research trends in Europe." International Journal of Environmental Research and Public Health 15(6): 1282.

Ge, Jiaqi, Lee-Ann, Sutherland, J. Gary, Polhill, Keith, Matthews, Dave, Miller, Douglas, WardellJohnson. 2017. "Exploring factors affecting onfarm renewable energy adoption in Scotland using large-scale microdata." Energy Policy 107: 548-560.

Goeldner, Charles R., and Brent Ritchie. 2012. Tourism: principles, practices, philosophies. Hoboken: Wiley.

Gössling, Stefan, Daniel Scott, and C. Michael Hall. 2020. "Pandemics, tourism and global change: a rapid assessment of COVID-19." Journal of Sustainable Tourism 29(1): 1-20.

Green Key. 2021. Green Key small accommodation criteria and explanatory notes. Accessed November 20, 2021. https://static1.squarespace. com/static/55371f97e4b0fce8clee4c69/t/5eff0f1 0648e2f5a44317222/1593773850773/Green+Ke $\mathrm{y}+$ small+accommodation+criteria+explanatory +notes+2016-2021-revision2018.pdf.

Greenglobe. 2021. Green Globe International Standard for Sustainable Tourism. Accessed November 20, 2021. https://www.greenglobe.com/. Gretzel, Ulrike, Matthias Fuchs, Rodolfo Baggio, Wolfram Hoepken, Rob Law, Julia Neidhardt, Juho Pesonen, Markus Zanker, and Zheng Xiang. 2020. "e-Tourism beyond COVID-19: a call for transformative research." Information Technology E Tourism 22: 187-203.

Haaland, Hanne, and Øystein Aas. 2010. "Eco-tourism certification - does it make a difference? A comparison of systems from Australia, Costa
Rica, and Sweden." Scandinavian Journal of Hospitality and Tourism 10(3): 375-385.

Hall, Colin Michael. 2008. Tourism planning: Policies, processes and relationships. Hoboken: Prentice Hall.

Higgins-Desbiolles, Freya. 2020. "Socialising tourism for social and ecological justice after COVID-19.” Tourism Geographies 22(3): 610-623.

Hjalager, Anne-Mette. 1996. "Agricultural diversification into tourism: Evidence of a European Community development programme." Tourism Management 17(2): 103-111. Huang, Wei-Jue, Beeco, J. Adam Hallo, Jeffrey C. Hallo, and William C. Norman. 2016. "Bundling attractions for rural tourism development." Journal of Sustainable Tourism 24(10): 1387-1402. https://doi.org/10.1080/09669582.2015.1115510.

Ilbery, Brian, Ian Bowler, Gordon Clark, Alastair Crockett, and Alastair Show. 1998. "Farm-based tourism as an alternative farm enterprise: A case study from the Northern Pennines, England." Regional Studies 32(4): 355-364.

Jaković, Božidar, Dejan Tubić, and Matina Đurović. 2015. "Sustainable development of rural tourism by developing new and authentic tourism products." 3rd International Scientific Conference Tourism in Southern and Eastern Europe. Accessed August 17, 2021. https://papers.ssrn.com/sol3/papers. cfm?abstract_id $=2637276$.

Jarvis, Nigel, Clare Weeden, and Natasha Simcock. 2010. "The benefits and challenges of sustainable tourism certification: A case study of the Green Tourism Business Scheme in the West of England." Journal of Hospitality and Tourism Management 17(1): 83-93.

Lenzen, Manfred, Ya-Yen Sun, Futu Faturay, YuanPeng Ting, Arne Geschke and Arunima Malik. 2018. "The carbon footprint of global tourism." Nature Climate Change 8(6): 522-528.

May, Murray. 2006. “Aviation Meets EcologyRedesigning Policy and Practice for Air Transport and Tourism." Transport Engineering in Australia 10(2): 117-128.

McCabe, Scott. 2019. ““Tourism for all?” Considering social tourism: a perspective paper." Tourism Review 75(1): 61-64. https://doi.org/10.1108/ TR-06-2019-0264.

Mei, Xiang Y., Ann-Margret S. Hågensen, and Heidi S. Kristiansen. 2020.”Storytelling through 
experiencescape: Creating unique stories and extraordinary experiences in farm tourism." Tourism and Hospitality Research 20(1): 93-104.

MKGP. 2020. Podatki registra dopolnilnih dejavnosti na kmetiji, 2018, 2019. (Internal material).

Mzembe, Andrew Ngawenja, Adam Lindgreen, Uwafiokun Idemudia, and Melissen Frans. 2020. "A club perspective of sustainability certification schemes in the tourism and hospitality industry." Journal of Sustainable Tourism 28(9): 1332-1350.

Niewiadomski, Piotr. 2020. "COVID-19: from temporary de-globalisation to a re-discovery of tourism?" Tourism Geographies 22(3): 651-656.

Oppermann, Martin. 1996. "Rural tourism in southern Germany." Annals of Tourism Research 23(1): 86-102.

Orlic, Ivona, and Kristina Brscic. 2012. "The Role of Hospitality in Agrotourism.” In Conference Proceedings of Tourism \& Hospitality Management 2012, 355-364. Accessed August 17, 2021. https:// www.bib.irb.hr/584327/download/584327.317_ Orlic.pdf.

Pan, Shu-Yuan, Mengyao Gao, Hyunook Kim, Kinjal J. Shah, Si-Lu Pei, and Pen-Chi Chiang. 2018. "Advances and challenges in sustainable tourism toward a green economy." Science of the Total Environment 635: 452-469. https:// doi.org/10.1016/j.scitotenv.2018.04.134.

Pearce, Philip L., and Gianna M. Moscardo. 1986. "The concept of authenticity in tourist experiences." The Australian and New Zealand Journal of Sociology 22(1): 121-132.

Peneva, Mariya, Yanka Kazakova-Mateva. 2015. "Local Food Systems and Rural Development in Bulgaria." Problems of World Agriculture/ Problemy Rolnictwa Światowego 15(4): 147-155.

Petroman Cornelia, Ioan Brad, Sorin Marin, Ioan Petroman, Iasmina Iosim, Adrian Firu, Diana Marin. 2017. "Types of Consumers of Agroturism." Agricultural Management/Lucrari Stiintifice Seria I, Management Agricol 19(1): 177-180.

Petrović, Marko D., Alon Gelbman, Dunja Demirović, Snježana Gagić, and Darko Vuković. 2017. "The examination of the residents' activities and dedication to the local community an agritourism access to the subject." Journal of the Geographical Institute 'Jovan Cvijic' SASA 67(1): 37-52.
Radnić, Romina Alkier, Vedran Milojica, and Danijel Drpić. 2012. "Sustainable Rural Tourism in Croatia and the Role of Cultural Resources." Journal of International Scientific Publications: Economy \& Business 6: 254-264.

Roman, Micha. 2015. "Agritourism farms owners' competence in running their economic activities." Polish Journal of Management Studies 11(1): 136-146.

Sargent, Caroline, and Stephen Bass. "The future shape of forests." In Policies for a Small Planet, edited by Johan Holmberg, 195-224. New York: Routledge.

Satumane, Anupam D., and Sedef Doganer. 2018. "Sustainable Rural Tourism Development Proposal at Mission Espada in San Antonio, Texas." Journal on Tourism \& Sustainability 1(2): 67-80.

Senturan, Sermin, and Nese Kokturk. 2017. "Applicability of Alternative Tourism: The Case of Zonguldak Province in Turkey." In Proceedings of the Global Conference on Services Management, edited by Cihan Cobanoglu, Fred De Micco, Patrick J. Moreo, and Alfonso Morvillo, 192-195. Bradenton: Association of North America Higher Education International.

Sharpley, Richard, and Adrian Vass. 2006. "Tourism, farming and diversification: An attitudinal study." Tourism Management 27(5): 1040-1052.

Sigala, Marianna. 2020. "Tourism and COVID-19: Impacts and implications for advancing and resetting industry and research." Journal of Business Research 117: 312-321.

SORS. 2020. Slovenia with record numbers of tourist arrivals and overnight stays in 2019. Accessed September 15, 2021. https://www.stat.si/StatWeb/ en/News/Index/8997.

SORS. 2021. In 2020, domestic tourists generated almost two thirds of all tourist overnight stays in Slovenia. Accessed September 15, 2021. https:// www.stat.si/StatWeb/en/news/Index/9435.

The Chamber of Agriculture and Forestry. 2018. Analysis of the state of supplementary activities. Accessed November 20, 2021. https://www.kgzs. si/uploads/dokumenti/strokovna_gradiva/analiza_ dopolnilnih_dejavnosti.pdf

Thilmany, Dawn, Rebecca Hill, Michelle Haefele, Andres van Sandt, Thomas Cullinane C., Martha Sullins, and Sarah A. Low. 2019. "Agri-tourism and Rural Outdoor Recreation in the US: A Framework 
for Understanding Economic and Employment Dynamics." In Rural Policies and Employment: Transatlantic Experiences, edited by Sophia M. Davidova, Kenneth J. Thomson, and Ashok K. Mishra, 351-372. Singapore: World Scientific.

TOMAS. 2010. Stavovi i potrošnja turista u Hrvatskoj, Ljeto 2010. Zagreb: Institute of Tourism. Accessed September 15, 2021. http://www.iztzg.hr.

Turistična kmetija pri Martinovih. 2021. Doživetja. Accessed November 20, 2021. https://www. martinovi.com/dozivetja

UNEP (United Nation Environmental Programme). 2003. Tourism and Local Agenda 21: The Role of Local Authorities in Sustainable Tourism. Paris; : United Nations Environmental Programme.

UNIS. 2021. Sustainable development goals. Accessed September 15, 2021. https://unis.unvienna.org/ unis/sl/topics/sustainable_development_goals. html.

UNWTO. 2004. Indicators of sustainable development for tourism destinations: A guidebook. Madrid: World Tourism Organisation.

UNWTO. 2019. International Tourism Highlights 2019. Accessed September 15, 2021. https://www. eunwto.org/doi/book/10.18111/9789284421152.

UNWTO. 2020. World Tourism Remains at a Standstill as 100\% of Countries Impose
Restrictions on Travel. Accessed September 15, 2021. https://www.unwto.org/news/covid-19world-tourism-remains-at-a-standstill-as-100of-countries-impose-restrictions-on-travel.

Villanueva-Álvaro, Juan-José, José MondéjarJiménez, and Francisco-José Sáez-Martínez. 2017. "Rural Tourism: Development, management and sustainability in rural establishments." Sustainability 9(5): 818.

Wall, Geoffrey, and Alister Mathieson. 2006. Tourism: change, impacts, and opportunities. Harlow: Pearson Education

WCED. (The World Commission on Environment and Development). 1987. Our Common Future. Oxford: Oxford University Press.

Williams, Allan M., and Gareth Shaw. 1998. Tourism and Economic Development: European Experience. Chichester: John Wiley.

Žibert, Maja, Boris Prevolšek, Karmen Pažek, Črtomir Rozman and Andrej Škraba. 2021. "Developing a diversification strategy of non-agricultural activities on farms using system dynamics modelling: a case study of Slovenia." Kybernetes https://doi.org/10.1108/K-04-2021-0254. 